\title{
Ķīmijas zinātnes ietekme uz farmāciju un farmaceitu praktisko darbu Eiropā, arī Latvijā viduslaiku un jauno laiku mijāa
}

\author{
Ilze Smiltena, Venta Šidlovska, Baiba Maurina
}

Farmācija ir viena no senākajām zinātnēm pasaulē, tā ir tik pat sena kā cilvēce, jo cilvēki vienmēr ir cietuši no dažādām slimībām un tādēl arī vienmēr ir meklējuši dažādus līdzekḷus, ar kuriem tās ārstēt un atvieglot to izraisīās ciešanas [1]. Tāpat cilvēki vienmēr ir meklējuši veidus, kā pagatavot šos ārstnieciskos līdzekḷus; līdz ar to var teikt, ka zāḷu formu tehnologijai ir tikpat sena vēsture, kā farmācijai un cilvēcei kopumā.

Laika gaitā uzskati par zāḷu līdzekḷiem mainijjās, taču to pagatavošanas procesa mērḳis vienmēr ir bijis panākt to vispilnīgāko iedarbību. Senos laikos šim mērḳim plaši izmantoja mağiju un misticisma elementus (Senajā Ėğiptē, Mezopotāmijā). Laika gaitā tie savu nozīmi zaudēja, jo pievienojās empīriski novērojumi un dažādas filozofiskas un zinātniskas atziņas (Senajā Grieḳijā, Senajā Romā, arābu zemēs).

Vairāku gadu tūkstošu laikā kopš pašiem farmācijas pirmsākumiem par zāļu līdzekliem izmantoja galvenokārt augus. Savukārt viduslaikos cilvēkos arvien lielāku interesi radīja dabā atrodamās vielas jeb minerāli, aizsākās plaši pētījumi par šo vielu īpašībām un to iespējamām pārmaiņām, iedarbojoties dažādiem faktoriem. Līdz ar to sāka attīstìties k,īmija, kuras atklājumus un sasniegumus drīz vien sāka izmantot arī medicīnā un zālu pagatavošanā. Liela nozīme bija arābu alḳimiḳiem, jo viṇi tālāk attīstīja antīkās medicīnas tradīcijas un radīja pamatus racionālas farmācijas tapšanai [2]. Vēlāk arābu alḳīmija izplatījās arī Eiropā. Renesanses laikmetā no tās izveidojās jatroḳīmija jeb ārstnieciskā kīmija, kas kḷuva par pamatu vēlākai zinātniskai farmācijai. Jatroḳimiḳi uzskatīja, ka cilvēka organismā notiekošajiem procesiem ir ḳimisks raksturs, tāpēc ar ḳīmiju ir jāsaista gan šo procesu izpēte, gan slimību ārstēšana [3].

Šajā laikā par zālēm sāka lietot ḷoti daudzas ḳīmiskas vielas (galvenokārt neorganiskās). Nozīmīgu ieguldījumu šā laikposma uzskatos devis Paracelzs (Philippus 


\section{Smiltena, V. Šidlovska, B. Maurina}

Aureolus Theophrastus Bombastus Paracelsus fon Hohenheim, 1493-1541), kas bija dzimis Šveicē, Cīrihes tuvumā. Viņš uzskatìja, ka "kermenis ir kīmiska laboratorija" [4], ka "taisnība ir nevis tiem, kas saka, ka alḳimija rada zeltu un sudrabu, bet tiem, kas saka, ka tā rada zāles un vērš tās pret slimībām" [5]. Vielām, kuras Paracelzs ieteica izmantot par zālēm, gan ne vienmēr bija ārstnieciska iedarbība, dažas no tām bija pat ḷoti spēcīgas indes (piemēram, dzīvsudraba, svina, antimona un citu smago metālu savienojumi) [6]. Paracelza ietekmē farmācija pārtapa no profesijas, kas primāri balstijās uz botānikas zināšanām, par zinātni, kas balstijās uz ḳimiju [4]. Alḳīmija un jatroḳimija pavēra jaunu lappusi farmācijas un zāḷu tehnolog̣ijas attīstībā, jo aizsākās plaši pētỉjumi k̦īmijā, kas ien̦ēma arvien nozīmīgāku vietu aptieku laboratorijās un kḷuva par stūrakmeni jaunu zāḷu pagatavošanā un ārstniecības lìdzekḷu daudzveidībā.

Tikai 18. gs. Eiropas aptiekāri pilnīgi pārṇēma pētījumus k̦īmijā, atstājot ārstiem medicīnu, lìdz ar to farmācija cieši saistijās ar k̦īmiju $[2,7]$.

Aptiekas bija iestādes, kuras nodarbojās ne vien ar zāḷu izsniegšanu, bet arī ar to pagatavošanu, tāpēc alkīmijas un arī jatroḳīmijas sasniegumu ietekmē tās kḷuva par kịmijas laboratorijām.

Lai zāḷu izstrāde kḷūtu efektīvāka, tika pilnveidoti dažādi tehnologiski procesi, radās arvien jaunas zāḷu formas, tika uzlabotas jau esošās, radītas jaunas laboratorijas iekārtas un trauki, tika pilnveidoti un radìti jauni materiāli to pagatavošanai. Attīstìjās arī analìtiskā ḳīmija, jo aptiekāri, kas bija reizē arī ķīmiķi, centās noskaidrot un izpētìt ķīmisko vielu sastāvu, viṇi rūpējas arī par zāḷu līdzekḷu kvalitāti. Franču ārsts un ķīmiķis Etjēns Fransuā Žofruā (Étienne François Geoffroy, 16721731) izstrādāja kvantitatīvās analīzes titrimetrijas metožu pamatus un sarakstijja darbu "Traktāts farmācijā" [8].

Lìdz ar ḳimijas nostiprināšanos aptiekāra praktiskajā darbā tā kḷuva arvien nozīmīgāka arī aptiekāru izglìtības procesā. Daudzu gadsimtu laikā aptiekāri zināšanas un prasmi apguva amatnieciskā veidā $[9,10]$. Lìdz pat 16.-17. gs. visā Eiropā topošā aptiekāra izglītošanās process galvenokārt bija saistīts ar praktisko darbu aptiekā pieredzējuša aptiekāra uzraudzībā. Tādā veidā aptiekāra māceklis pēc noteiktu zināšanu iegūšanas un eksāmenu nokārtošanas varēja uzsākt patstāvīgas darba gaitas aptiekā. Aptiekā iegūtās zināšanas bija pietiekami augstvērtīgas, jo tādā veidā savu pirmo izglîtību ieguva daudzi vēlāk slaveni zinātnieki [11]. Tikai 18. gs. farmaceitiskā izglìtība sāka pārvietoties no aptiekāru gildēm uz universitātēm, to ietekmēja visu zinātṇu nozaru straujā attīstība. Lai iegūtu pilnvērtīgu izglìīibu, topošajam aptiekāram bija jāveic vairāki priekšnoteikumi:

1) vispārēja izglìtîba (liceja diploms vai līdzvērtīga izglìtîba);

2) profesionālā izglīîiba (četri kursi universitātē);

3) profesionālā pieredze (viens gads praktiskā darbā pieredzējuša aptiekāra uzraudzībā pēc universitātes kursa pabeigšanas);

4) eksāmenu kārtošana, kuros topošajam aptiekāram bija jāpierāda gan teorētiskās zināšanas (arī likumdošanā), gan praktiskās zināšanas [4]. 
Šādi izglìtības pamatprincipi pastāvēja gandrīz visā Eiropā, tomēr dažās valstīs bija atšķirības teorētiskās izglìtības un prakses ilguma ziņā.

İpatnēja farmaceitiskās izglìīibas sistēma 18. gs. pastāvēja Vācijā, kur farmaceiti bija sadalīti divās klasēs. Otrās klases aptiekāriem bija aṭ̂uts strādāt tikai mazās pilsētās, taču viniem nebija obligāta akadēmiskā izglìīiba. Aptiekāra mācekḷa gaitas parasti ilga piecus gadus, tad sekoja sešu gadu ilgs aptiekāra palīga darbs, pēc tam vajadzēja nokārtot eksāmenus, lai varētu strādāt patstāvīgi. Savukārt pirmās klases farmaceitiem par aptiekāra mācekḷiem bija jānostrādā pieci gadi, pēc tam sekoja septiņus gadus ilgs aptiekāra palīga darbs, turklāt bija jāapmeklē akadēmisks kurss augstākās izglìtības iestādē Berlīnē, kur izglìīibu ieguva militārie ārsti un kirurgi. Akadēmiskais kurss ietvēra lekcijas ḳīmijā un botānikā, mācību par ḳimiskām vielām, kuras izmantoja par ārstniecỉbas līdzekḷiem, to pagatavošanu, citus priekšmetus. Farmaceitu dalījums divās klasēs Vācijā izzuda 19. gs. vidū [4].

Arī Lielbritānijā jau 17. gs. sākumā bija noteikts, cik ilgi personai jāstrādā par aptiekāra mācekli, kādi eksāmeni jānokārto, lai varētu strādāt pilsētu aptiekās. Nākamā gadsimta laikā kā obligāta prasība pievienojās arī noteiktu lekciju ciklu apmeklējums universitātē. İstu farmaceitisko izglìtîbu universitātē Lielbritānijā varēja iegūt tikai pēc tam, kad 1841. gadā nodibināja Farmaceitu savienību [4], kura par vienu no svarīgākajiem un primārākajiem uzdevumiem uzskatīja mācību iestādes izveidošanu, kurā varētu iegūt farmaceitisko izglìtību [12].

Akadēmiskās aptiekāru izglītỉbas studijas Francijā tika ieviestas 1536. gadā. Aptiekāra mācekliiem bija jāapmeklē divas lekcijas nedēḷā par aptiekāra mākslu, jo tikai tad viṇi varēja kḷūt par aptiekāru meistaru. No 1558. gada Monpeljē universitātē varēja iegūt akadēmisko farmaceita izglìtîbu. Arī Francijā aptiekāri tika iedalīti divās klasēs: pirmās klases farmaceitiem bija ațauts praktizēt visā valstī, bet otrās klases aptiekāri drīkstēja strādāt tikai tajā apriņ̣̂ī, kurā bija kārtojuši eksāmenu [4].

Itālijā ilgu laiku pastāvēja noteikums, ka vispirms noteikts laiks jānostrādā par aptiekāra mācekli, pēc tam - par aptiekāra palīgu, visbeidzot jānokārto sarežğìts eksāmens, lai varētu patstāvīgi strādāt aptiekā. 1778. gadā tika ieviestas akadēmiskas studijas, līdz ar to farmaceitiskās izglìtības iegūšana no ğildēm pārvietojās uz universitātēm [4].

Zviedrijā līdz 19. gs. sākumam aptiekāri amata prasmi apguva aptiekā pieredzējuša aptiekāra vadībā, pēc tam kārtoja eksāmenus, kas l̦āva uzsākt patstāvīgas darba gaitas. 1837. gadā tika izveidota Aptiekāru biedrība, kura kā vienu no saviem mērḳiem izvirzijja "izveidot un vadīt institūtu, kurā jaunieši, kas nolēmuši sevi veltìt aptiekāra profesijai, varētu iegūt zināšanas ḳimijā, farmācijā, materia medica, dabasvēsturē, latīnu un vācu valodā" [1].

Arī aptiekāri, kas darbojās Latvijas teritorijā, izglìtību ieguva līdzīgā veidā. Līdz 17.-18. gs. tās bija profesionālas mācības aptiekās pieredzējuša aptiekāra uzraudzībā. Kad nodibinājās universitātes, Latvijas aptiekāri devās galvenokārt uz 


\section{Smiltena, V. Šidlovska, B. Maurina}

dažādām Vācijas universitātēm (Hallē, Jēnā, Leipcigā, Getingenē) [13], bet sākot no 1802. gada - arī uz Tērbatu, jo Latvijas teritorijā nebija nevienas augstskolas, kurā varētu iegūt farmaceitisku izglìīibu.

Par kịmijas ietekmes palielināšanos aptiekāru izglìtībā un darba gaitās liecina arī vairāku tālaika aptiekāru sasniegumi. Tā, piemēram, viens no ievērojamākajiem vācu ḳimiķiem tehnologiem Johans Rūdolfs Glaubers (Johann Rudolph Glauber, 1604-1670) pētīja neorganiskos sāļus, ko izmantoja zāḷu pagatavošanai. Viṇš pirmais radīja pareizu priekšstatu par sāḷu uzbūvi, viṇa vārdā nosaukts nātrija sulfāts un amonija sulfāts. Glaubers nodarbojās arī ar augu ekstrahēšanu ar paskābinātu ūdeni, iegūstot stipras iedarbības izvilkumus, kuros bija alkaloīdu sāḷi (šìs iedarbīgās vielas pašas gan atklāja vēlāk). Viņš izveidoja ḳimisku laboratoriju, kurā tika izgatavotas ķīmiskas vielas, lai tās tālāk pārdotu aptiekā [8]. Glaubers bija arī viens no pirmajiem, kas sāka laboratorijas traukus izgatavot no stikla. Viņš iemācījās iegūt krāsainu stiklu un nodibināja stikla ražošanas uzn̦ēmumu. 1661. gadā Glaubers apkopoja savus eksperimentus un novērojumus septinos sējumos. Tam bija liela ietekme k̦īmiskās rūpniecības tehnologiju attīstîbā $[2,7]$.

Nozīmīgu ieguldījumu farmācijas attīstībā devuši arī citi aptiekāri. Piemēram, Andreass Zigismunds Margrāfs (Andreas Sigismund Marggraf, 1709-1782) nodalīja nātrija un kālija savienojumus, atklāja magniju, nodarbojās ar dažādu metālu savienojumu iegūšanu, ieviesa praksē vairākus reaǵentus, pierādīja vairākos augos cukuru, izskaidroja atškiriību starp minerālskābēm un organiskajām skābēm $[8,4,14]$. Margrāfs, kas tā arī nebija ieguvis universitātes izglìtību, vairāk nekā 20 gadu pārvaldīja sava tēva izveidoto aptieku un ilgus gadus vadīja Berlīnes Zinātṇu akadēmijas kīimijas laboratoriju [14].

Vācu farmaceits Johans Volfgangs Dēbereiners (Johann Wolfgang Döbereiner, 1780-1848) bija k̦īmijas profesors Jēnā. Viņš atklāja platīna katalītisko efektu, ko izmantoja, lai veiktu dažādas k̦īmiskas reakcijas, piemēram, etilspirtu pārvērstu par etiksskābi (1821), bet pēc tam - par acetaldehīdu (1832) [8]. Viņš radīja arī sistēmu, kas uzskatāma par periodiskās sistēmas priekšteci [4].

18.-19. gs. aptiekās notika arī tirdzniecība ar vienkāršām dabas vielām (simplica), tajās pagatavoja un pārdeva galēniskos preparātus (composita), kā arī izstrādāja kị̄miskos zāḷu līdzekḷus, no kuriem pagatavoja zāḷu formas, ko izmantoja slimnieku ārstēšanā [14]. Līdz ar to aptieku laboratorijas uzskatāmas par farmaceitisko ražotṇu priekšgājèjām, dažas no šìm laboratorijām laika gaitā ḳ̣uva par k̦īmiskām rūpnīcām, kuru primārais uzdevums bija zāḷu izstrāde un ražošana [14]. Tā, piemēram, attīstījās Merck, Schering, Riedel u. c. farmācijas rūpniecības uzṇēmumi.

Lìdz ar ḳīmijas ienākšanu aptieku laboratorijās mainījās arī aptieku darbības regulēšanas principi. Lìdz 18. gs. aptiekas bija cieši saistītas ar medicīnu, ko pārraudzīja un noteikumus diktēja ārsti. Lìdz ar kīmijas nozīmes palielināšanos aptieku darbībā un aptieku laboratoriju pārveidošanos par nelielām kịmiski farmaceitiskām iestādēm ārsti zaudēja savu nozìmi to darbības uzraudzībā, un ap- 
tiekāri ieguva plašākas noteikšanas tiesības pār saviem arodbrāliem. Tas spilgti izpaudās Vācijā, jo citās Eiropas valstīs, piemēram, Itālijā un Francijā, kur aptiekāri bija apvienojušies ǵildēs, viņi spēja pārstāvēt savas intereses jau vairāku gadsimtu laikā [4].

Mainoties aptieku darbības profilam, kā arī aptieku darbības uzraudzības un regulējošo normatīvu izstrādes gaitā lielāku nozīmi ieguva paši aptiekāri, it ìpaši Vācijā, jo ar ārstu zināšanām medicīnā nu vairs nebija pietiekami, lai varētu efektīvi ārstēt slimniekus [4]. Aptieku darba kontrole tika veikta rūpīgi, arī paši aptiekāri pārsvarā centās strādāt pēc labākās sirdsapziņas, lai šādas kontroles nesagādātu viņiem nepatīkamus pārsteigumus. Šādu pārbaužu rezultātā tapa ziņojumi, kuros tika uzslavētas Rīgas aptieku laboratorijas, piemēram, par Mazās aptiekas laboratoriju varam lasīt, ka tā ir "ērta laboratorija, kurā valda kārtỉba un tīîiba" [10].

Protams, ne jau visi 18. gs. aptiekāri savās aptiekās veica plašu zinātnisko darbību un nodarbojās ar farmaceitisko rūpniecỉbu, - lıti daudzas aptiekas iepirka lielāko aptieku saražotās zāles un pārdeva tās tālāk [14].

Vèlīno viduslaiku un agrīno jauno laiku mijā aptieku laboratorijas savu artavu devušas arī zāḷ formu attīstībā. Izvilkumu un novārījumu pagatavošana aptiekās tika veikta jau pirmajās aptiekās un pat vēl pirms to rašanās [14]. Arī destilācijai ir pietiekami sena vēsture - jau 10. gs. arābi aprakstija šās metodes izmantošanu farmaceitiskiem mērḳiem [8]. 1833. gadā ekstraktu pagatavošanai sāka izmantot perkolāciju (nosaukums cēlies no latīnu vārda percolare - iztecināt cauri). Metodes pamatā bija konisks trauks, kurā ievietoja sasmalcinātu drogu kopā ar šḳīinātāju, kuru pēc noteikta laika notecināja. Pastāv uzskats, ka perkolators esot izdomāts kafijas pagatavošanai un 19. gs. sākumā plaši izmantots Parīzes kafejnīcās. No turienes trauks un pagatavošanas princips pārceḷojis uz fitoḳimiskajām laboratorijām, bet no tām - uz aptiekām galēnisko preparātu pagatavošanai [15].

Ar jatroḳimijas uzplaukumu un k̦īmijas ienākšanu aptieku laboratorijās paplašinājās to darbības spektrs, līdz ar to arī aptiekāru praksē parādījās aizvien jaunas tehnolog̣ijas un tehnolog̣iskie pañēmieni, kurus ieviesa aptieku ikdienā, piemēram, iztvaicēšanu, smalcināšanu, šķīdināšanu, izgulsnēšanu, oksidēšanu, sakausēšanu u. c. [14].

Lai aptieku laboratorijas pilnvērtīgi varētu nodarboties ar zāļu līdzekḷu pagatavošanu, tām bija nepieciešams aprīkojums. Tur noteikti atradās krāsns, jo karsēšana un sildišana tika ļoti bieži izmantotas zāḷ pagatavošanas procesā. Tajās noteikti bija arī daudzveidīgi destilācijas aparāti, kā arī dažādi trauki un instrumenti. Ne visas aptiekas bija bagātīgi aprīkotas, bieži vien ārpus pilsētām esošajās aptiekās nebija nekādu īpašu laboratorijas iekārtu, jo tās pašas nenodarbojās ar zāılu pagatavošanu [14].

Šajā laikā aptieku laboratorijās aptiekas trauku (mērtrauku, kolbu, mazāku un lielāku pudeḷu u. c.) pagatavošanai sāka izmantot stiklu, kaut arī tas sākumā bija ḷoti dārgs. Visvecākais materiāls, no kura tika gatavoti aptiekas stāvtrauki, 


\section{Smiltena, V. Šidlovska, B. Mauriṇa}

bija koks, kas savu nozīmi lētuma dēl nezaudēja līdz pat 20. gs. sākumam. Retāk izmantoja metālu, piemēram, svinu un alvu, bet pavisam reti - zeltu un sudrabu, īpaši traukiem, kuros glabāja visdārgākās zāles [10]. No 18. gs. sāka izmantot porcelāna traukus, arī fajansa, māla, keramikas un akmens trauki tika plaši izmantoti [10]. Porcelāna trauki bija ḷoti iecienīti Itālijā, jo ikviens aptiekārs vēlējās parādīt savu rocību, novietojot aptiekas plauktos greznus fajansa traukus un krūkas, kurās glabāja dārgas zāles [4]. Daudzi aptiekas trauki un ierīces bija tādi paši, kādus savā darbā izmantoja kīmiḳi - krāsnis, destilācijas aparāti, krūkas, tìgelị, retortes, svari, piestas, filtri u. c. [14].

Lai gan mūsdienās farmācija un precizitāte ir nesaraujami jēdzieni, līdz pat 18. gs. otrajai pusei svari un termometri bija vienīgie precizie instrumenti, kas bija atrodami ikvienā laboratorijā [14]. Rìgas aptieku praksē izmantoja Nirnbergas svaru sistēmu, kurā mērvienība bija aptiekas mārciṇa (libra) - aptuveni 360 g, ko iedalīja arī mazākās mērvienībās [10].

Daudzas zāḷu formas (pulveri, šḳìumi, ūdens izvilkumi, ziedes, supozitoriji, kompreses, putrinas u. c.) bija pazīstamas jau senajos laikos, bet laika gaitā tās tika uzlabotas, jo kopš pirmsākumiem cilvēki centās panākt pilnīgāku zālu iedarbību. Jau Senajā Griekijā bija zināms, ka to var panākt, iegūstot tīrāku zāḷu vielu vai aktīvāku vielu kompleksu.

Pētot dažādos laikmetos sastādìtās farmakopejas un citus izdevumus par zālēm, var secināt, ka 17.-19. gs. paplašinājās zāḷu lỉdzekḷlu nomenklatūra: plašāks kḷūst ne tikai ḳimisko līdzekḷu klāsts, nāk klāt arī no augu izcelsmes izejvielām iegūti produkti, kas līdz tam nebija pazīstami. Aptieku laboratorijas nodarbojās ar šādu zāḷu formu pagatavošanu: tinktūras, zāḷu etiḳi un vīni, esences, ekstrakti, balzami, zāḷu eḷ̦as, sīrupi, pulveri, tabletes, zirnīši, zāl̨u tējas, mikstūras, emulsijas, pilieni, ziedes, pastas, putriņas u. c. [10]. 1833. gadā sāka izmantot želatīna kapsulas, no 1838. gada tabletes sāka apvalkot ar medu un Gummi Arabicum pulveri. 1842. gadā tika radīta pirmā tablešu prese [8].

Eiropā, it īpaši Vācijā, no aptieku laboratorijām izauga vairāki ķīmiski farmaceitiski uzṇēmumi. Jau minēto farmaceitisko firmu E. Merck dibināja aptiekārs Heinrihs Emanuels Merks (Heinrich Emanuel Merck, 1794-1855). Sākotnēji tā darbojās kā laboratorija, kas bija izveidota Darmštatē, pie Eņgeḷa aptiekas, kuras vadīšanu viņš bija pārṇēmis no sava tēva, bet 1843. gadā viņš izveidoja jaunu laboratoriju, kas atradās ārpus Darmštates. Merka uzṇēmums savos pirmsākumos nodarbojās ar alkaloīdu (morfina, narkotīna, strihninna, hinīna u. c.) ražošanas tehnoloǵiju [14]. Šis uzṇēmums nepārtraukti paplašinājās. Mūsdienās tas ir izaudzis par milzịgu farmaceitisku koncernu.

Arī aptiekārs Johans Dāniels Rīdels (Johann Daniel Riedel, 1786-1843) bija izveidojis pie savas 1814. gadā iegādātās aptiekas laboratoriju, kas ražoja hinīnu. 1844. gadā Rỉdela kompānijas sortimentā bija 570 preparātu [8]. 1874. gadā laboratorija no aptiekas atdalījās un turpināja darbu kā farmaceitisks uznēemums arī nākamajā gadsimtā. Šādam paraugam sekoja vēl citas aptieku laboratorijas. Šās 
rosības pamatā bija nerimstošs aptiekāru darbaprieks, plašās zināšanas, rūpes par savas profesijas cieṇu sabiedrībā, vēlme nodot savas zināšanas un amata prasmi nākamajām paaudzēm, kas turpinātu un attīstītu vinuu iesākto darbu.

19. gs. otrajā pusē aptiekas un aptiekāru stāvoklis bija mainījies, jo aptieku zinātniskā nozīme bija mazinājusies; ḳīmisko vielu ražošana sāka attīstīties rūpnieciskos mērogos, aptiekām tika atstāta tikai tirgotāja loma. Tas prasija nopietnas reformas aptieku darbā un farmaceitiskajā izglìtībā. Aptiekāriem bija jācīnās par savām tiesībām un savu stāvokli sabiedrībā, kā arī jāmeklē atbalsts valdošajās aprindās. 19. gs. aptiekāri tika galā ar šîm problēmām un 20. gs. tie palika tikpat cilvēkiem nepieciešami kā iepriekš.

\section{Vēres}

1. Sandel, E. Pharmaceutics. Stockholm: Swedish Pharmaceutical Press, 1983. 242 p.

2. Семенченко, В. Ф. История фармации. Москва, Ростов на Дону: Март, 2003. $640 \mathrm{c}$.

3. Сорокина, Т. С. История медиииньы. 6. изд. Москва: Академия, 2007. 560 с.

4. Sonnendecker, G. Kremers and Urdang's History of Pharmacy. 3rd ed. Philadelphia, Montreal: J. B. Lippincott Company, 1963. 464 p.

5. Штрубе, В. Пути развития химии. Т. 1. Москва: Мир, 1984. 204 с.

6. Gedeon, A. Science and Technology in Medicine: An Illustrated Account Based on Ninety-nine Landmark Publications from Five Centuries. Berlin: Springer, 2006. $551 \mathrm{p}$.

7. Frederking, C. Grundzüge der Geschichte der Pharmacie und derjenige Zweige der Naturwissenschaft, auf welchen sie basiert. Göttingen, 1874. 303 S.

8. Семенченко, В. Ф. Хроника фармации. Москва: Альфа-М, 2007. 640 с.

9. Vỉksna, A. Farmācijas augstskolas tradicionālie model̦i Latvijā. Materia Medica, 2001, Nr. 12, 22.-23. lpp.

10. Vīksna, A. Vecās aptiekas. Rīga: Zinātne, 1993. 160 lpp.

11. Левинштейн, И. И. История фармации и организация фармацевтического дела. Москва, Ленинград: Наркомздрав СССР, Медгиз, 1939. 223 с.

12. Anderson, S. Making Medicines: A Brief History of Pharmacy and Pharmaceuticals. London: Pharmaceutical Press, 2005. 318 p.

13. Stradiņš, J., Cēbere, Dz. Zinātnes un augstskolu aizsākumi Rīgā (līdz 19. gs. pirmajai pusei).//Senā Rìga 3: Pètījumi pilsētas arheoloǵijā un vēsturē. Rìga: Latvijas vēstures institūta apgāds, 2001, 375.-407. lpp.

14. Klein, U. Apothecary shops, laboratories and chemical manufacture in eighteenth-century Germany.//The mindful hand: inquiry and invention from the late Renaissance to early industrialisation. Amsterdam: Edita, 2007, p. 246-276.

15. Parrish, E. An Introduction to Practical Pharmacy. Philadelphia: Blanchard and Lea, $1859.720 \mathrm{p}$. 


\section{Influence of Chemistry Science on Pharmacy and Practical Work of Pharmacist in Europe in the Turn of medieval Times and Early Period (Summary)}

\author{
By Ilze Smiltena, Venta Šidlovska, Baiba Maurina
}

Interest about minerals increased in Medieval Times, wherewith researches in chemistry were initiated. Discoveries and achievements of chemistry were shortly used also in medicine and in preparation of medicines. Together with development of chemistry rational foundation for pharmacy was created. Pharmacy transformed from artisan trade to academic and scientific profession. Apothecary's shop also changed: the preparation and dispensing of natural simple drugs and Galenic preparations were tasks of apothecary's shops since the beginnings of their origin in the late ancient times. Preparation, manufacturing and selling of different chemical remedies joined to these tasks in turn of time periods from medieval times to early period. These laboratories can be considered as small pharmaceutical factories - foregoers of modern pharmaceutical industry manufactures, where some kind of scientific and research work was also performed. Some of these laboratories located in Europe grew as large pharmaceutical manufactories, and some of them have survived till nowadays.

Baiba Mauriņa

e-pasts: baiba.maurina@rsu.lv 